\title{
Significance of Biotechnology Clusters in Terms of Sustainable Development and Clustering Proposal for Antalya Province, Turkey
}

\author{
Aise Sukran Karadayi ${ }^{1} \&$ Bekir Sami Oguzturk ${ }^{1}$ \\ ${ }^{1}$ Department of Economics, Suleyman Demirel University, Isparta, Turkey \\ Correspondence: Aise Sukran Karadayi, Department of Economics, Suleyman Demirel University, Isparta, \\ Turkey.
}

Received: August 17, 2012 Accepted: October 17, 2012 Online Published: October 26, 2012

doi:10.5539/jsd.v5n11p56

URL: http://dx.doi.org/10.5539/jsd.v5n11p56

\begin{abstract}
As global economy progress and world population increases, the effects of rapid industrialization and polluting activities of population is seen as depletion of natural resources and pollution of ecosystems. Thus, countries have come to a conclusion to implement sustainable development principles in their economic activities. Several international treaties have been signed and Turkey is a signatory of most of these treaties. In the study the necessity of the development of biotechnology sector is emphasized in order to achieve sustainable development objectives that have been recently recognized in Turkey. Antalya is chosen as the case because it is a developing city, with high immigration rate, rapid industrialization and mass tourism activities (approx. 11 million incoming tourists annually) which increases rapid consumption of natural resources in addition to increased environmental damage. Biotechnology industry offers cleaner solutions and applications for consumer demands. In the study, the potential and the necessity of forming a biotechnology cluster in Antalya is discussed. A SWOT analysis is included and the research is made through sectoral visits, conference calls and workshops as part of the field researches of West Mediterranean Development Agency.
\end{abstract}

Keywords: sustainable development, biotechnology cluster, biotechnology, clusters, Antalya, Turkey

\section{Introduction}

The $21^{\text {st }}$ century has witnessed crucial alterations in terms of economic structure, growth strategies and global problems. New economics featuring knowledge based sectors faces some crucial social, economic and environmental problems with the effect of population increase, aging, changes in disease structures, increase in the demand of natural resources (Tepav, 2012).

Fordist mass production techniques have been adopted by industries until the 1970s because it provides speed and standardization of production processes, low unit cost, low labour costs and easy marketing of products. As a result of uncontrolled industrial mass production; imbalances in environment, human health and ecosystem has been experienced from the 1970s on, thus the concept of sustainable development revived. Sustainable development is development that meets the needs of future generations without compromising the ability of future generations to meet their own needs. To achieve this goal, while producing and consuming people should care the balance of environment and natural resources, and also the social welfare equity should be carefully observed.

Competition has intensified hence the strategy of cost reduction alone is not sufficient for global markets. Furthermore state-of-the-art technology, innovative product, process and service supply, and contribution to sustainable development have also gained importance. On the other hand, carbon credits, increases in product health controls, increasing level of consumer-consciousness with social media are the mechanisms that make industrialists embrace the principles of sustainable development.

Biotechnology which is described as 'sustainability's silver bullet' is an interdisciplinary field of study (Williams et al). Main application areas of biotechnology are medicine, industry, agriculture and environmental sciences. Biotechnology offers much more sustainable production systems in all these sectors. Another advantage of biotechnological products is energy efficiency and easier recycling and disposal of wastes and by-products. United Nations Convention on Biological Diversity Treaty, one of the Rio Treaties, which was signed by Turkey in 1994, postulates regulating uses and distribution of biotechnology benefits. 
Recently, there have occurred many progresses in the health sector in Antalya. There are international biomedical companies mostly situated in Antalya Free Trade Zone. High agricultural production also enables biotechnology clusters to be formed. Besides the existence of West Mediterranean Agricultural Research Institute, Akdeniz University Research Centre for Agricultural Biotechnology and Suleyman Demirel University Biological Control Research and Application Centre would support the formation of biotechnology cluster. Exports of fresh fruit and vegetables, biological, pharmaceutical, and enzyme applications or residue to the development of green biotechnology sector require the development of disease-free species. It is necessary to develop green biotechnology sector which would promote residue-free biological control and genetic engineering for obtaining disease-free plant species in the region. In addition, biotechnology cluster would support existing seed sector cluster. Sustainable development is very crucial for Antalya, particularly as a well-known tourism destination. In the study, the potential and the requirement of the creation of a biotechnology cluster in Antalya is examined in the context of sustainable development.

\subsection{Sustainable Development}

The sustainability of natural resources in the globalising world has become a common problem for all countries. Sustainable development, the most frequently discussed and studied issue by developed and developing countries, tries to meet the needs of current generations without compromising the ability of future generations to meet their own needs.

- Sustainable development is a form of development in which all the resources are used in a way that meet the needs of future generations (Tietenberg, 1992).

- Sustainable development is a development strategy which manages natural resources, human resources, physical and financial wealth for the long-term prosperity and humanity (Repetto, 1992).

- Sustainable development is a set of political and ethical actions which respond to the right of future generations and institutions (O'Riordan, 1988; Gurluk, 2010).

Until the 1970s, development policies of countries stick to persistent economic growth based on the assumption that natural resources were unlimited without evaluating mass production principles, speed in production processes, standardization, low unit cost, low labour cost and easy marketing opportunity and its effects. As a result of the fact that rapid industrialization and uncontrolled resource consumption caused environmental disasters and poverty, the need to take precautions was realized. The Club of Rome published Limits to Growth Report which is known as Medow Report. The report emphasises that uncontrolled economic growth and population growth should be prevented and the mutual dependence of the natural environment with economy should be taken into account by development policies; otherwise due to ongoing process resources would run out in a very short time.

The basis of the sustainability idea is the declaration on the human environment which was agreed at the United Nations Conference held in Stockholm. It is a major turning point in the sustainable development politics. Declaration contains 26 principles which concern the capacity of environment, intergenerational equity in resource use; which establish economic and social development in connection with the environment, and which emphasize the unity of development and the environment.

United Nations Environment Program (UNEP) was established in the conference and it became a common platform for international environmental issues. To prevent marine pollution and ozone depletion, global and local networks were established. Nevertheless, 26 principles and action plan adopted at the conference have never been seriously implemented. The impact of development on the environment continues (Lahiry, 2010).

The concept of sustainable development was first used in IUCNs (International Union for Conservation of Nature and Natural Resources) World Conservation Strategy Report and was defined as protecting natural resources for the future (Allen \& Edwards, 1995).

"Our Common Future Report" (also known as the Brundtland Report) which was published by World Commission on Environment and Development (WCED) in 1987, defines sustainable development as the development that meets the needs of the present without compromising the ability of future generations to meet their own needs. Therefore it highlights intergenerational equity.

The report aims equitable distribution of resources, restructuring the means of economic growth, population control, the development of environmentally compatible technologies and also the eradication of poverty.

Sustainable development concept was also addressed in The United Nations Conference on Environment and Development (UNCED) held in Rio de Janerio in June 1992. The organisation is also known as The Earth 
Summit and it published Agenda 21, the Rio Declaration as the resulting document.

27 principles of the Rio Declaration declared common but differentiated responsibilities for all countries on environmental management and development. They highlight that women and indigenous people have a vital role in protecting environment and that countries shall cooperate, protect and restore the health and integrity of the Earth's ecosystem. The Rio Declaration is a set of principles imposing politic responsibilities to governments concerning environment and social development. Yet it has no binding on the legal rights and obligations of countries.

United Nations Framework Convention on Climate Change (UNFCCC) is the first environmental contract signed against global warming under the leadership of the United Nations. Turkey is also a signatory of the convention. The convention recognizes negative impacts of human-induced environmental pollutions on the climate. Therefore it aims to reduce greenhouse emission rates and maintain a certain level, and regulate overall governmental principles, strategies and obligations. Despite its weakness in terms of enforcement power, countries supported the convention in good faith.

Kyoto Protocol was the first concrete step to achieve the ultimate objective of convention which was enacted on February $16^{\text {th }}, 2005$. The protocol was signed by industrialized and a few Centre European Countries that promised to reduce greenhouse emission rates nearly 6-8\% between 2008-2010 compared to the level in 1990 . The United States of America which has the largest greenhouse emission rate in the world, promised to reduce 7\% of its total greenhouse emissions but its government explicitly announced in 2001 that they rejected the protocol.

The protocol was signed in 1997 but entered into force in 2005 as the obligation of decreasing the total emissions by $55 \%$ was difficult to attain, especially without the contribution of Russia. Kyoto Protocol encompasses 191 countries and more than $55 \%$ of total greenhouse emissions. The measures introduced by the Protocol require expensive investments. Although Turkey is a partner of United Nations Framework Convention on Climate Change in 2004, she has not signed the protocol for a long time but approved the reduction of carbon gasses until 2013 with the Cabinet Decision on February $5^{\text {th }}, 2009$. One of the major regulations of the protocol is the tax regulations concerning fuel consumptions and carbon productions. Besides, carbon markets and credits have emerged with the Protocol. Carbon producer countries and exceeding countries on carbon quotas can get credits on current market prices. Carbon credits also contributed to firms in terms of sustainable development.

Millennium Declaration was published by United Nations as a result of Millennium Summit which was signed by representatives of 147 countries in September, 2000. United Nations General Assembly adopted 60 goals at Millennium Summit on peace, development, environment, human rights and especially for the problem of hunger in Africa.

Specific objectives such as the reduction of poverty by the year 2015 were adopted in Millennium Declaration. 8 specific objectives under "Millennium Development Goals" are monitored by international organizations (Kates et al., 2005). 8 objectives which are allocated to a special fund under the Millennium Goals are as follows:

(1) Eradicating extreme poverty and hunger,

(2) Achieving universal primary education,

(3) Promoting gender equality and empowering women,

(4) Reducing child mortality rates,

(5) Improving maternal health,

(6) Combating HIV/AIDS, malaria, and other diseases,

(7) Ensuring environmental sustainability, and

(8) Developing a global partnership for development.

In order to measure the efficiency of decisions and implementations in the post-World Summit 1992 period and create effective development strategies to overcome problems, Sustainable Development Summit (also known as Rio +10 ) was held in Johannesburg between August $26^{\text {th }}$ and September $4^{\text {th }}$. As a result of Rio +10 , Johannesburg Declaration and Plan was adopted. Desertification, biodiversity loss, global warming, natural disasters, air and water pollution are mentioned as the main environmental problems in the Declaration.

20 years after the first World Summit which had been held in Rio, "United Nation Sustainable Development Conference" (also known as Rio +20 ) was held again in Rio between June $13^{\text {th }}$ and $22^{\text {nd }}, 2012$. Regulations and projects implemented by countries and best practices from past to present were evaluated in the conference. 


\subsection{Significance of Biotechnology Clusters in Terms of Sustainable Development}

Today the effective use of scarce resources, the implementation of environment-friendly industrial production techniques and contribution to sustainable development have become an obligation for competitiveness. Sustainability within industrial context is related to clean technologies and also known as green technological systems. Biotechnological methods supplement chemical methods for ensuring the clean technologies in many cases. For this reason many countries support biotechnological systems and encourage them to sustain economic activities. Some countries, such as Taiwan, try to leave petrochemical industry and entirely replace it with biotechnology (http://www.chinapost.com.tw/taiwan/national/national-news/2011/05/19/302936/Ma-wants.html).

According to OECD's Technology Policy and Environment Report in 2002, environmental improvements would increase when governments transfer their resources to information technologies, biotechnologies and nanotechnologies through increasing use of these technologies. Governments in OECD countries, make cooperation with private sector for the production of "clean" cars using bio-fuel and transfer significant resources for biotechnological researches. Also in OECD countries, some researches continue for the proliferation of environment friendly technologies in SMEs (Uysal, 2003). The use of biotechnology and the distribution of its benefits are one of the provisions of United Nations Convention on Biological Diversity in Rio's Convention, signed by Turkey in 1994.

Biotechnology, also described as "The silver bullet of sustainability" is an interdisciplinary field of study (http://www.aabri.com/manuscripts/10661.pdf). Main implementation areas of biotechnology are medicine, industry, agriculture and environment.

Biotechnological production systems can be applied to almost every industrial sector and have cleaner and sustainable principals than chemical production systems that can be defined as the process of raw material to the formation of waste products. According to the definition of Biotechnology Institute in 2005, biotechnology is "the developing tools and products by benefiting from biology, chemistry, physics, and engineering, computer and information technologies".

Majority of the raw materials used in biotechnology (agricultural products such as microorganisms) are easily accessible, renewable and sustainable. Importance of renewal of the raw material is easily understood when the fact that more than $90 \%$ of the raw materials used in chemical industry are from fuel oil and natural gas is taken into account. As an example, the use of enzymes instead of using chemical sulphates in detergent industry, cleaner and biodegraded detergents can be produced and these detergents can also be used in lower temperatures that, in turn, means energy saving.

Biotechnology industry is divided into four main branches.

Blue biotechnology refers to ocean and aquatic biotechnology which uses aquatic algae, invertebrates, bacteria, fungi to produce bioactive compounds, biofilms, enzymes, drugs, cosmetics, nutraceutics and biopolymers which can be used in several industries. Biofuel production from algae, spirulina production which is a dietary supplement and bioremediation of oil pollution in marine ecosystems are other examples of blue biotechnology applications. Bioremediation, currently regarded as an emergent technology, has become the main application of environmental biotechnology. The term denotes any treatment based on the use of biological systems for the restoration or sanitation of soils, underground waters and atmospheric air contaminated with xenobiotics (Martin, 2011). Furthermore the application of "marine genomics" as a prospective strategy for finding new substances also requires only small amounts from environmental samples (http://www.submariner-project.eu/index.php?option=com_content\&view=article\&id=96\&Itemid=231).

Green biotechnology is biotechnology applied to agricultural processes. An example is the selection and domestication of plants via micropropagation. Another example is the design of transgenic plants to grow under specific environments with (or without) chemicals. An expectation is that green biotechnology might produce more environmentally friendly solutions than traditional industrial agriculture. An example of this is the engineering of a plant to express a pesticide, thereby ending the need of external application of pesticides. An application of this would be BT corn. Whether or not green biotechnology products such as this are ultimately more environmentally friendly is a topic of considerable debate.

Red biotechnology is applied to medical processes. Some examples are stem cell techniques, design of organisms to produce antibiotics, hormones, production of biomedical devices, cancer cell-targeted smart drugs, biochips, biomechatronics and engineering of genetic cures through genetic manipulation.

White biotechnology, also known as industrial biotechnology, is the biotechnology applied to industrial processes. An example is the design of an organism to produce a useful chemical. Another example is the use of enzymes as 
industrial catalysts in order either to produce valuable chemicals or to destroy hazardous/polluting chemicals. White biotechnology tends to consume fewer resources than traditional processes used to produce industrial goods (http://www.articlesbase.com/science-articles/biotechnology-an-applied-sciences-1934607.html).

Utilization of clean biotechnology applications in industrial production, energy production, agricultural activities and to develop biotechnology sector would be more accurate than searching for short-term temporary solutions to pollution and excess usage of natural resources.

\subsection{The Potential of Biotechnology Clustering in Antalya}

According to 2012 data of Antalya Chamber of Commerce and Industry (CCI) there are 79 companies in Antalya operating in various activities of biotechnology sector. Most of them perform in fertilizer production and plant protection, and seed production. Those companies operating in the field of medical biotechnology concentrate in Antalya Free Zone. There are international companies such as Maquet, Fresenius and Nocamed that leads the sector. There are 4 molecular biotechnology companies operating in Antalya techno-city. There are 20 companies operating in the field of seeding and making conglomeration efforts in the region. Besides, there are companies producing fermented drinks, waste elimination and enzyme for the textile sector. All the firms behave independently and have no mutual actions, except seeding firms. Here there is the need of conglomeration.

Although there are efforts initiated with the creation of Biotechnology Expertise Commission founded with the $7^{\text {th }}$ Development Plan in Turkey, there is still no roadmap specific to biotechnology. In the last 10 years, academic studies on biotechnology have intensified, and the number of departments of bio-engineering, and molecular biology and genetics has increased. In the meanwhile private sector has stirred, and the number of biotechnology companies founded by entrepreneurs in the techno-cities has increased. However, as the distribution of bio-technological patents is examined by Figure 1, the current situation of biotechnology in Turkey is insufficient (Tepav, 2012).

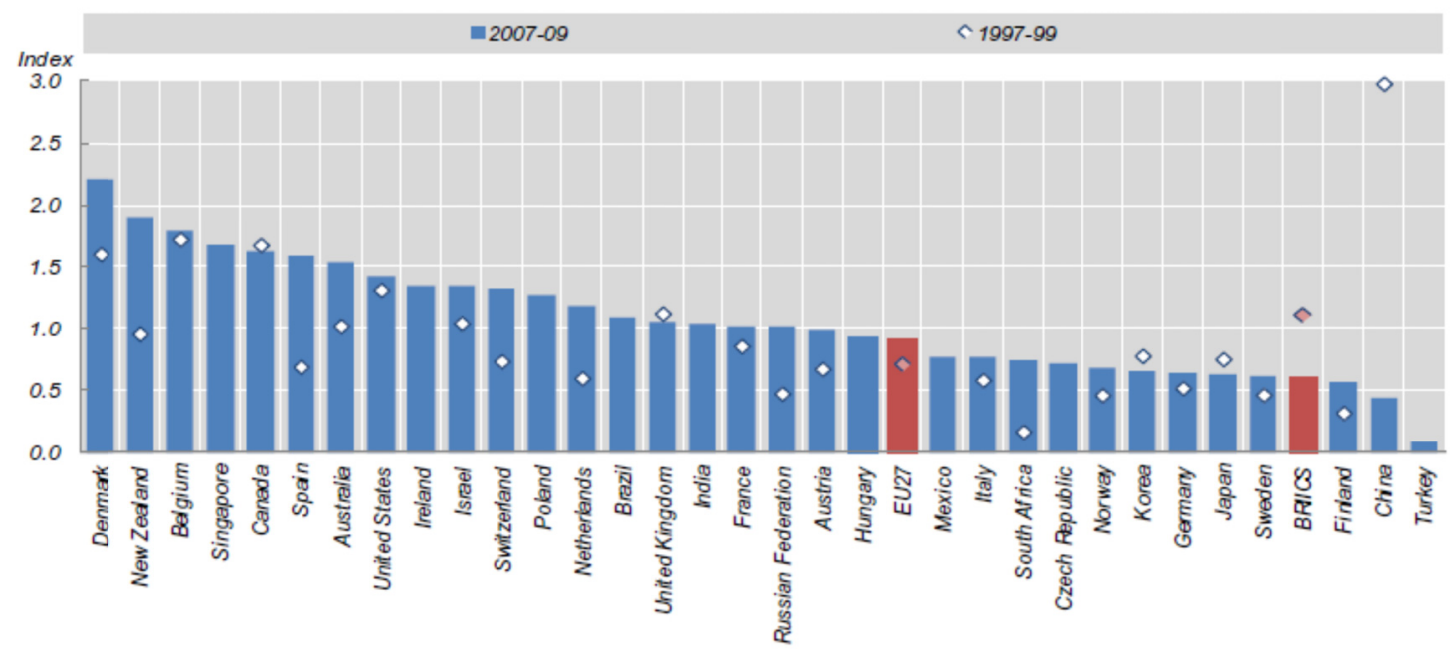

Figure 1. The distribution of bio-technological patents

Source: OECD, 2011, Key Biotechnology Indicators.

According to data from ABPRS (Address Based Population Registration System) 2010-2011 net migration rate to Antalya is $13.23 \%$ and Antalya ranks second in Turkey in terms of migration rates. As rapid industrialization does, mass tourism activities also increases consumption of natural resources and causes environmental damage. Consequently sustainable development practices and measures are crucial for the prevention of further deterioration of existing natural structures. In addition, conservation of natural resources and environment requires special attention for the sustainability of tourism sector. In this context, for maintaining sustainable development in Antalya, technologies that are compatible with environment and human health should be promoted.

Antalya is specialized in agricultural production and modern agricultural practices are applied in the region. Therefore 3 harvests may be realised annually. With a 5.2 billion worth of agricultural product, in terms of fresh fruit and vegetables production Antalya ranks first in Turkey. Also it has $83 \%$ of the glass greenhouses and 52\% 
of the plastic greenhouses in Turkey. Antalya realises 17\% of Turkey's total fresh fruit and vegetable export and in turn generate an income of US \$2,3 billion (TEA - Turkey Exporters Assembly, 2011; www.tim.org.tr). Besides, 46 of 102 total vegetable seeds companies in Turkey, 52 of 79 seedling companies in Turkey is located in Antalya (http://www.antalya-tarim.gov.tr/index_tr.asp?mn=27\&in=5788). Research centres located in the region such as West Mediterranean Agricultural Research Institute, Seed and Agricultural Biotechnology Research and Application Centre of Akdeniz University and Suleyman Demirel University Biological Control Research and Education Centre would provide research and education basis for forming a biotechnology cluster. Preference of biological control, and environment and human health-friendly biopreparats to harmful chemical pesticides for plant protection; application of agricultural biotechnology techniques for the improvement of quality and yield of the product; increases in the number and quality of agricultural biotechnology companies in the region should be achieved to ensure sustainability in agricultural production. Instead of chemical fertilizers and pesticides the preference of biotechnological agents would enhance competitiveness of products in international markets, would prevent returns of exported products and would also serve to sustainable development.

There are international biomedical companies, medical biotechnology companies which operate in stem cell and cord blood bank applications. Especially recently, Medicine Faculty of Akdeniz University has come up with successful organ transplantations. To avoid transplant rejection, immunosuppressive drugs are given to patients, usually lifelong. As these drugs suppress patient's natural immune system, they may cause infections and some serious diseases such as cancer and make patient sensitive to illnesses. By injecting stem cells before the transplantation, the patient's immune system becomes compatible with the organ. Additionally, with further bioengineering methods, it would be possible to build an organ or tissue with patient's own stem cells. Cultivating medical biotechnology would also accelerate these researches and applications.

The presence of fermented beverage industry and companies producing biodegradable detergent and enzymes for treatment systems would serve as a basis for the development of white (industrial) biotechnology. Development of industrial biotechnology in the region is essential especially for the preservation of natural beauties and marine water quality. Kumluca greenhouse region produces biogas plant waste which would provide 40 million KWh of electricity annually. Other districts (e.g. Alanya) carried power plant installation projects. A biogas plant project for Kumluca region would digest greenhouse wastes and would also contribute to sustainable development. These kinds of projects have become a model for other towns and interestingly for Alanya itself.

In addition, the seed sector cluster to be formed within the activities of UNDP and cosmetic cluster to be formed in Isparta can be integrated to biotechnology cluster as biotechnology covers these sectors. One of the most important features of French cosmetics cluster is its integration with biotechnology cluster. By integrating plant tissue culture applications, seed and seedling sectors would gain competitiveness in international markets and R\&D and innovation studies would speed up.

\section{Method}

The SWOT analysis data is collected through sectoral meetings, conference calls and workshops in Antalya, as the part of the researches of the West Mediterranean Development Agency. West Mediterranean Development Agency is a governmental regional institution funded by central government and local authorities such as municipalities and chambers of commerce and industry. Regional development agencies are established for the purpose of local development, primarily economic. The Agency's main missions are;

- collecting data in local base and determining region's potentials and requirements,

- preparing regional plans which are compatible with national plans,

- implementing financial or technical support programmes for supporting projects which would serve to reach the goals that are determined in the regional plans,

- monitoring and evaluating projects which are funded by the agency,

- contributing to the improvement of the capacity of the region concerning rural and local development,

- improving cooperation among public and private sectors and NGOs,

- ensuring effective and efficient utilization of resources,

- promoting business and investment facilities in the region,

- following and coordinating permissions and licenses needed by investors in the region (serving as a one-stop shop for investors) 
- $\quad$ supporting SMEs and new entrepreneurs in cooperation with other related institutions,

- promoting activities related to bilateral or multilateral international programmes (http://www.baka.org.tr/kalkinma-ajanslarinin-alisma-usul-ve-esaslari-hakkinda-yonetmelik-S26.html).

As can be seen, searching new ways to advance local development and to develop new sectors in the region to compete globally is a mission of regional development agencies. For this purpose and particularly for understanding the potential of biotechnology sector development in the region, sectoral meetings, company visits, conference calls, town-based meetings, polls and workshops were organised. Especially biotechnology companies were visited to question about strengths, weaknesses of the sector and opportunities and threats to the sector.

West Mediterranean Agency organized 7 workshops in various sectors, which can be listed as agriculture and food industry workshop in Antalya and neighbouring cities Isparta and Burdur, R\&D and innovation workshop, local authorities and youth Workshop, transport workshop and tourism workshop. Additionally 19 town-based meetings were carried out. 422 people who work for either public sector or private sector or local authorities or NGOs were surveyed. The polls included general questions about understanding region's needs, potentials and threats. Also, investment support offices, located in Antalya, Burdur and Isparta, all the companies and SMEs were scanned through regular visits that allowed in-depth interviews. Results of town-based meetings and polls were brought together and published as reports; the data is also used in preparing regional plans. The data that is collected during the interviews were reported monthly to the Board of Directors and annually to the Ministry of Development and to public opinion.

\section{Results}

\subsection{SWOT Analysis for the Potential of Biotechnology Clustering in Antalya}

\subsubsection{Strengths}

- There is management, raw material and market potential for developing biotechnology sector in Antalya.

- Supporting sectors (food, agriculture and health) for a biotechnology cluster exist in the city.

- Faculty of Medicine, Akdeniz University and medical biotechnology companies are located in Antalya.

- Technopolis is an opportunity for the development of red biotechnology sector.

- The existence of internationally recognized biomedical companies in Antalya Free Trade Zone.

- The existence of fermented beverage industry and companies that produce biodegradable detergent and enzymes for treatment systems (for the development of industrial biotechnology).

- The biogas plant which digests greenhouse wastes in Kumluca would be a model for other investors.

- 'Biological Control Research, Practice, Production and Education Centre Project' which was elected in the call for proposals under the 'Best Practices in the Field of Sustainable Development and Green Growth in Turkey' was presented in Rio+20 World Summit and it would be a model and pioneer for the development of green biotechnology in the region.

- Extensity of endemic plants in the region (there are 478 endemic plant species in Antalya which makes it the richest region in terms of endemic plant extensity in Turkey) would enhance drug discoveries and enzyme developments, and hence red and green biotechnological sectors.

- The existence of advanced and modern agricultural practices in the province, Seed and Agricultural Biotechnology Research and Application Centre of Akdeniz University, West Mediterranean Agricultural Research Institute and biotechnology laboratory in Provincial Food Control Laboratory would all provide infrastructure for the development of agricultural biotechnology sector.

- There are areas on Mediterranean coasts and other wetlands suitable for cultivation of algae which can be used to produce a variety of enzymes, drugs and biofuels.

\subsubsection{Weaknesses}

- There are not enough cluster elements yet to form a biotechnology cluster in Antalya.

- Cooperation is not a common sense in the region.

- There are few biotechnology specialists in the region.

- Lack of information in public institutions and local governments about biotechnology. 


\subsubsection{Opportunities}

- The seed sector cluster to be formed within a project of UNDP, tourism and food sector cluster potential in Antalya

- The aggregation of cosmetic sector in Isparta can be integrated to biotechnology cluster. As Michael Porter (2008) has indicated integrated clusters which have similar marketing tools and similar customer segments are much more successful than individual clusters.

- The opportunity to integrate with health tourism sector in the province.

- The competitiveness of fresh vegetables and fruit sector located in the province would increase with edible and/or biodegradable packaging produced via industrial biotechnology.

- Biofuel can be produced from plants like safflower and canola which do not require much care on sloping terrains and on fields that have become unproductive because of overuse.

- Biogas can be produced from wastes of touristic facilities which are high in organic compounds.

- The presence of funding organizations and technical support agencies in the region.

- The presence of well-trained bioengineers and biotechnologists in Turkey.

- When the cluster is formed, R\&D and innovation would be encouraged constantly, accordingly competitiveness of the sector would increase.

\subsubsection{Threats}

- $\quad$ Biotechnology is still a new field in Antalya

- As a result of misinformation about GMOs, public opinion against biotechnology may rise.

- There is not enough adoption and internalization of sustainable development in the region.

The results of the SWOT analysis are parallel with the results of the SWOT analysis made in 'Strategic Priorities for Biotechnology Program' in Saudi Arabia (Kingdom of Saudi Arabia Ministry of Economy and Planning, King Abdulaziz City for Science and Technology, 2008-2012). In the study, the current situation of biotechnology sector in Saudi Arabia is assessed and the strengths are determined to be the existence of research institutes and master's degrees. As in the case of Antalya, attention was drawn to the existence of sufficient number of companies and institutions for cluster incubation. Furthermore, the existence of adequate financial sources, the existence of modern communication infrastructure and easy access to databases are stated as strengths. Also, as in the case of Antalya, the lack of the culture of mutual study preparation by entrepreneur scientists in the sector is mentioned as weakness. The difficulty of attracting foreign researchers and entrepreneurs is also mentioned. The lack of cooperation and inter-institutional coordination are explicit weaknesses of both regions. Besides the opportunities specific to the region, high financial returns of biotechnology are common opportunities for both regions. The threads are indicated as the weak interest to biotechnology sector, and non-labelling biotechnology sector as a privileged sector in the region.

As in the case of Antalya, in a bio-technological SWOT analyses published by an Indian business portal called Naukrihub the lack of public awareness on biotechnology is mentioned as a thread (http://www.naukrihub.com/india/biotechnology/overview/swot/).

In a study encompassing SWOT analysis for the development of industrial biotechnology in the EU, the USA and BRICs (Brazil, Russia, India and China), the fact that GMOs and transgenic plants, in contrast to Turkish case, are accepted by the public in the USA and BRICs is mentioned and entitled as strength.

The high production of agricultural raw materials used in the biotechnology sector in the EU countries and BRICs is mentioned as strength in Antalya case. The common strengths of the USA, the EU and Japan are their strength in biotechnology sector and their R\&D capacities. The oppositeness of the public in the EU countries and in Turkey to GMOs is accepted as a thread in front of the sector (KET - Industrial Biotechnology, 2011).

\section{Results and Discussion}

Antalya is a rapidly industrializing city; with natural and historical attractions, and vast agricultural areas where agricultural and tourism activities can be performed throughout the year because of its mild climate. For ensuring the sustainability of these economic activities and natural resources for future generations, using clean biotechnological methods in industry, agricultural production and energy production would be more accurate than searching temporary solutions.

The study is considered as a proposal in order to reveal the potential of biotechnology cluster in Antalya. A 
cluster analysis is made if a sector concentrates in a particular region. However biotechnology is a new sector for Antalya and most companies which are operating in biotechnology sector is registered under other sectors as food, agriculture, and medical. Due to the necessity of conducting a more sustainable industrial development in Antalya a proposal was needed.

Screening of existing industries that have connections with biotechnology, and examining new enterprises empirically should be done in further studies. Also a road map for establishing biotechnology cluster must be prepared. In the San Diego biotechnology cluster case, one of the world's most important biotechnology clusters, it is reported that the most important component in the formation of the cluster is R\&D and innovation fund support, and the existence of research institutes in the country. Federal funds allocated for research projects fuel the development of new technologies and these new technologies have been reported to be commercialized in small biotechnology companies and articulated to economy. Additionally, it is reported that the funding supports the critical mass of scientific researchers in the region, many of whom may either create their own companies, or be hired by local firms, or become scientific advisors to companies in the region (Global Connect, 2010). Based on this, redirecting private sector to use new and sustainable technologies by public institutions, giving priority to $R \& D$ innovation activities by funding agencies would strengthen the cluster.

\section{References}

Allen, M. C., \& Edwards, S. R. (1995). The Sustainable-Use Debate: Observations from IUCN. Oryx, 29(2), 92. http://dx.doi.org/10.1017/S0030605300020950

Global Connect. (2010). Biotechnology Cluster Project, San Diego Analysis. The US Studies Centre. p. 11.

Gurluk, S. (2010). Can Sustainable Delopment Be Applied to Developing Countries? Eskişehir Osmangazi University. Journal of School of Management, 5(2), 85-99.

Kates, R. W., Parris, T. M., \& Leiserowitz, A. A. (2005). What is Sustainable Development, Goals, Indicators, Values and Practice. Environment: Science and Policy for Sustainable Development, 47(3), 8-21. http://dx.doi.org/10.1080/00139157.2005.10524444

KET - Industrial Biotechnology. (2011). Working Group Report (pp. 14-18).

Kingdom of Saudi Arabia Ministry of Economy and Planning and King Abdulaziz City for Science and Technology. (2008). Strategic Priorities for Biotechnology Program, (2008-2012, pp. 24-26).

Lahiry, S. (2010). Environment, Sustainable Development and Climate Change: A Critical Review. Journal of Peace Studies, 17(2\&3), 1-2.

Martin, Y. B. S. (2011). Bioremediation: a tool for the management of oil pollution in marine ecosystems. Biotecnología Aplicada, 28(69-76), 70.

OECD. (2011). Key Biotechnology Indicators.

Porter, M. (2008). On Competition. Optimist Publishing.

TEA - Turkey Exporters Assembly. (2011). http://www.tim.org.tr/tr/

Tepav. (2012). Towards, Bioeconomy: Where is Turkey in this Process? Politika Notu, Şubat 2012, pp. 3-5.

Uysal, A. (2003). Sustainable Development: A General Perspective. SPO Thesis.

Williams, K., Brooks, K., Page, M. Biotechnology: Sustainability's Silver Bullet. Journal of Sustainability and Green Business. http://www.aabri.com/manuscripts/10661.pdf

http://www.antalya-tarim.gov.tr/index_tr.asp?mn=27\&in=5788

http://www.articlesbase.com/science-articles/biotechnology-an-applied-sciences-1934607.html

http://www.baka.org.tr/kalkinma-ajanslarinin-alisma-usul-ve-esaslari-hakkinda-yonetmelik-S26.html

http://www.chinapost.com.tw/taiwan/national/national-news/2011/05/19/302936/Ma-wants.html

http://www.naukrihub.com/india/biotechnology/overview/swot/

http://www.submariner-project.eu/index.php?option=com_content\&view=article\&id=96\&Itemid=231

http://www.tim.org.tr 